\title{
Effect of arbuscular mycorrhizal fungi on the acclimatization of micropropagated banana plantlets
}

\author{
Accepted: 24 May 1999
}

\begin{abstract}
The effect of arbuscular mycorrhizal fungi (AMF) on micropropagated banana plantlets was evaluated during the acclimatization period. Plants were inoculated with Acaulospora scrobiculata, Glomus clarum or Glomus etunicatum. After cultivation in a greenhouse for 3 months, height, leaf area, fresh weight and dry matter of root and shoots, level of AMF colonization, nutrient level, photosynthesis and transpiration rate, water potential and stomatal conductance were measured. The number of AMF spores produced in each treatment was also determined. Plantlets inoculated with AMF had greater height, leaf area and fresh weight of shoots and roots, as well as higher rates of photosynthesis and transpiration than controls. Plants inoculated with Glomus were superior in most of the evaluated parameters.
\end{abstract}

Key words Musa spp. Endomycorrhiza - Glomales · Acclimatization

\section{Introduction}

The vegetative micropropagation of fruit, ornamental and forest species is the main tool for producing genetically homogeneous plants in a good phytosanitary condition and in large numbers. The transfer to the greenhouse of plants cultivated in vitro is one of the most important steps in the structural and physiological adaptation during preparation of plantlets. This phase, known as acclimatization, is the beginning of the autotrophic existence of the plant, with the initiation of the physiological processes necessary for survival. During

A.M. Yano-Melo $(\mathbb{\square}) \cdot$ L.C. Maia

Departamento de Micologia, CCB,

Universidade Federal de Pernambuco,

50670-420, Recife-PE, Brazil

e-mail: amymelo17@hotmail.com

O.J. Saggin Jr. · J.M. Lima-Filho · N.F. Melo Embrapa Semi-Árido, Cx. Postal 23, 56300-000, Petrolina-PE, Brazil this time, plantlets must increase absorption of water and minerals and the photosynthetic rate (Grattapaglia and Machado 1990).

Micropropagated plantlets are free of diseases, but they also lack arbuscular mycorrhizal fungi (AMF). AMF are known to increase the vigor of plants by increasing absorption of water and mineral nutrients, especially phosphorus (P). Moreover, AMF can protect host plants from root pathogens and mitigate the effects of extreme variation in temperature, $\mathrm{pH}$ and water stress (Dixon and Marx 1987; Siqueira 1994).

Successful inoculation of AMF at the beginning of the acclimatization period (Granger et al. 1983; Brazanti et al. 1992; Guillemin et al. 1995) or even during in vitro cultivation (Mathur and Vyas 1995) has been demonstrated. The beneficial effect of the symbiosis formed with the root system of plants from tissue culture manifests itself in the development of vigorous plants with high photosynthetic and transpiration rates, improved absorption of nutrients and water and increased stress tolerance (Azcón-Aguilar et al. 1997; Jaizme-Vega et al. 1997).

Inoculation of micropropagated plants with AMF during initial growth ex vitro may contribute to high colonization rates through positive mycorrhizal symbiosis effects on the activity of the rootmeristem. This hypothesis is supported by results of Berta et al. (1995), who demonstrated that AMF association altered the branching pattern of roots of Prunus cerasifera. The inoculum type used in the acclimatization is important. Fortuna et al. (1992) recommended the use of infective and efficient species of AMF which promote rapid increase in plant growth. These authors also demonstrated, while comparing the efficiency of two AMF species in promoting growth of micropropagated $P$. cerasifera, that the infectivity of the fungi influenced their effectiveness. Greater fresh and dry matter and height increases were found with plants inoculated with Glomus mosseae than with $G$. coronatum, but at the end of the experiment both groups of plants showed similar growth. 
The aim of our work was to evaluate the effects of the inoculation of three native AMF species isolated from irrigated banana plantations of the Brazilian semiarid region on growth, nutrition and physiology of banana plantlets developed in vitro.

\section{Materials and methods}

Plant material and soil properties

Micropropagated banana plantlets(Musa spp. cv. Pacovan) were obtained from the Laboratory of Biotechnology, Embrapa SemiÁrido, Petrolina-PE, Brazil. The plantlets formed roots in vitro using MS liquid culture medium (Murashige and Skoog 1962) and were later transferred to plastic cups $(500 \mathrm{ml}$ capacity) filled with a fumigated (Bromo flora Methyl Bromide, Bromine Compounds Ltd., Beer Sheva, Israel) substratum: soil, sand, and organic matter $(1: 1: 1)$. The properties of the soil before mixture with sand were $3.2 \mathrm{~g}$ organic matter $\mathrm{kg}^{-1}$ soil, $0.84 \mathrm{mg} \mathrm{P} \mathrm{dm}{ }^{-3}$ soil (Mehlich I), pH 5.1 (soil: water 1:2.5). The inoculum (approximately 400 spores per container) was placed $5 \mathrm{~cm}$ below the soil surface in contact with the banana plantlet roots and was covered with fumigated substratum. A filtrate of the inoculum soil was added to all treatments to standardize microbiota. Plants were maintained in the greenhouse under a 12-h light period of 800-1300 lux, $25 \pm 4^{\circ} \mathrm{C}$ and $70-90 \%$ relative humidity.

\section{Inoculum source}

Spores of Acaulospora scrobiculata (isolate AcSc PE 002) andGlomus etunicatum (isolate GIEt PE 004) were isolated from the rhizosphere of banana plantations in the Submédio São Francisco Valley, Petrolina, Pernambuco, while inoculum of Glomus clarum (isolate UFPE08) was obtained from the culture collection of the Embrapa Agrobiologia, Seropédica, Rio de Janeiro. The isolates were cultivated in a greenhouse for 4 months in 3-1 containers filled with a mixture of soil, sand and vermiculite $(2: 1: 1)$ and planted with Panicum miliacium. The plants were irrigated with nutrient solution (Hewitt 1966) on alternate days and with distilled water once a week.

\section{Data collection}

Three months after inoculation, percent root colonization, number of spores, shoot and root fresh and dry weights, plant height, and leaf area were measured. Physiological parameters such as photosynthesis, transpiration, stomatal conductance, and water potential were also examined. Spores were extracted from the soil by water and sucrose centrifugation (Jenkins 1964). Roots were stained with $0.05 \%$ trypan blue (Phillips and Haymann 1970) and percent colonization was estimated by the gridline-intersect meth-

Table 1 Means of growth parameters and mycorrhizal colonization of banana plantlets (Musa spp. cv. Pacovan) inoculated or not with arbuscular mycorrhizal fungi (AMF) and the number of AMF spores after 3 months acclimatization. Values followed by od (Giovannetti and Mosse 1980). Plant height was measured directly and leaf area determined by a Leaf Area Meter Li 3100 (LI-Cor Inc. Lincon, Neb., USA). Photosynthesis, transpiration and stomatal conductance rates were measured with a portable photosynthesis system Li-6200 (LI-Cor) coupled to a 250-ml assimilation chamber. For determination of water potential, leaf discs ( $1 \mathrm{~cm}$ diameter) were collected and transferred to psychometric chambers (C-52) connected to a microvoltmeter (HR 33T Wescor).

\section{Experimental design}

The following treatments were established: (1) Without inoculation (2) inoculated with Acaulospora scrobiculata (3) with Glomus clarum (4) with G. etunicatum. The experiment was randomized with five replicates. For analysis of variance the data on percent colonization and number of spores were arcsin transformed as the square roots of $(\mathrm{x} / 100)$ and $(\mathrm{x}+2.5)$, and statistical differences among means evaluated by Tukey's Test using the SAS program (SAS Institute).

\section{Results}

\section{Plant growth}

After 3 months of acclimatization, statistically significant differences in plant height, leaf area, fresh and dry matter of shoot, and fresh weight of roots between inoculated and non-inoculated plants were recorded (Table 1).

Leaf area and height of inoculated plants were approximately $57 \%$ and $32 \%$ higher, respectively, than non-inoculated plants. Dry matter of shoots increased $45-64 \%$ in mycorrhizal plants. Banana plantlets inoculated with $G$. clarum showed an increment of around $45 \%$ in the fresh weights of shoots and roots over noninoculated plants. Root percent colonization and spore number were not significantly different among the treatments (Table 1$)$.

\section{Physiological aspects}

Banana plantlets inoculated with A. scrobiculata and $G$. etunicatum reached the highest photosynthetic rates, being $45 \%$ more efficient than the non-inoculated plants.

the same letter are not significantly different $(P<0.05)(D W$ dry weight, $F W$ fresh weight, AcSc Acaulospora scrobiculata, $G l C l$ Glomus clarum, GlEt Glomus etunicatum)

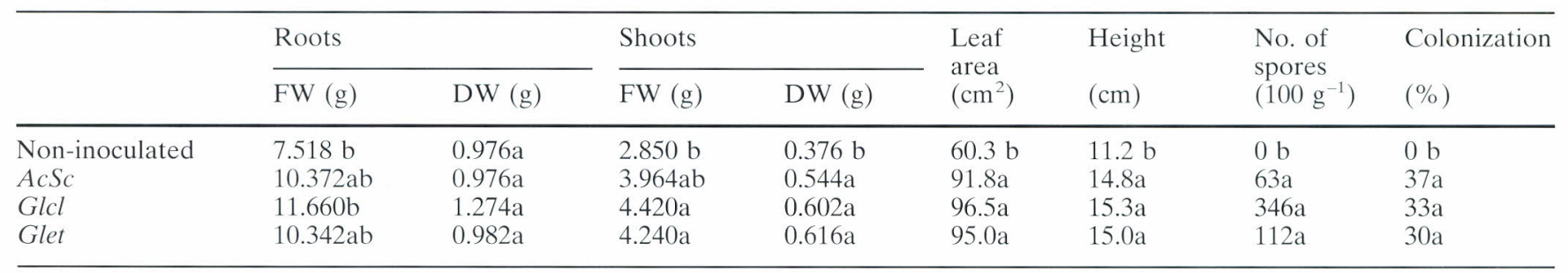


Table 2 Nutrient contents of roots and shoots of micropropagated banana plantlets. Values followed by the same letter are not significantly different $(P<0.05)$



There was an increase in stomatal conductance in plants inoculated with AMF and an increase in the transpiration rate of $60-86 \%$. These increases were especially clear in banana plantlets inoculated with $A$. scrobiculata. In contrast, the water potential of banana plantlets inoculated with $A$. scrobiculata was not affected and was marginally increased in plantlets inoculated with Glomus isolates (data not shown).

\section{Nutrient absorption}

The nutrient contents of the root systems of AMF-inoculated banana plantlets only differed significantly from the control for copper $(\mathrm{Cu})$, sodium $(\mathrm{Na})$ and magnesium $(\mathrm{Mg})$ (Table 2). The $\mathrm{Cu}$ content was increased most in banana plantlets inoculated with $A$. scrobiculata. The $\mathrm{Na}$ content of plantlets inoculated with Glomus species was $70-95 \%$ higher than that of the control plantlets (Table 2), while for $\mathrm{Mg}$ a higher content was found in the control than in plants inoculated with $G$. etunicatum.

Differences in the contents of $\mathrm{K}, \mathrm{Ca}, \mathrm{Mg}, \mathrm{Mn}$ and $\mathrm{Zn}$ were found in shoots of micropropagated banana plantlets (Table 2). Mycorrhizal plantlets had higher contents of $\mathrm{Zn}$ and $\mathrm{Mn}$ than the control. Conversely, the contents of $\mathrm{K}, \mathrm{Ca}$ and $\mathrm{Mg}$ were higher in the control (Table 2) than in plants inoculated with $G$. etunicatum.

$\mathrm{Fe}$ and $\mathrm{Na}$ accumulated to higher levels in roots than in shoots. In contrast, most of the absorbed Mn was transferred to the shoots (Table 2).

\section{Discussion}

Plant height, leaf area and dry matter of shoots of inoculated banana plantlets were significantly higher than those of control plants. These results reinforce those obtained by Monteiro et al. (1991), who presented height as the parameter showing the most significant differences in cultures of banana (variety Mysore) ino- culated with G. clarum. Lin and Chang (1987) also obtained increased height, diameter of the pseudostem, and dry matter weight of banana plantlets inoculated with species of Glomus, 4 months after transplant from in vitro culture to the greenhouse.

Thus Glomus species are apparently effective in promoting growth of banana plantlets. Declerck et al. (1994) reported that $G$. mosseae was more effective than G. geosporum at improving growth of micropropagated banana plants. Later, Declerck et al. (1995) observed that promotion of growth varied among banana cultivars and that plants inoculated with G. macrocarpum grew more than those inoculated with G. mosseae. The growth stimulation was associated with increased phosphorus in shoots. Results obtained in our experiments show that $G$. clarum as well as the native $G$. etunicatum and A.scrobiculata are effective in promoting growth of banana plantlets during the acclimatization period, with little difference in the effectiveness of the three species.

AMF colonization did not differ among the inoculated treatments in this study. Declerck et al. (1995) found differences in colonization of banana cultivars by AMF isolates. According to Douds et al. (1998), the physiological response of a plant is the resultant of interactions between environment, plant, and fungus genotype. It is worthwhile to point out that increases in growth rate are not always related to colonization (Guillemin et al. 1992), but may be influenced by other factors, such as extension of the external mycelium and transport of nutrients from the soil to the host.

Jaizme-Vega et al. (1991) observed that root fresh matter of micropropagated banana plantlets (Musa acuminata Colla AAA, subgroup Cavendish) increased simultaneously with increase in root colonization by $G$. mosseae and $G$. fasciculatum. Although these experiments were over a longer time period than ours, root colonization was lower than we observed. Nevertheless, AMF inoculation led to similar increases in root fresh weight in the two experiments. This difference in levels of root colonization by AMF is probably attributable to differences in mycorrhizal dependency among varieties of banana and to abiotic factors. 
Increased leaf area observed by Allen et al. (1981) and Harris et al. (1985) was concomitant with an increase in photosynthetic rate of Bouteloua gracilis that was thought to be an effect of inoculation with $G$. fasciculatum. In contrast, Freeden and Terry (1987) in reporting results obtained with Glycine max inoculated with $G$. fasciculatum observed a similar increase in leaf area but not in photosynthetic rate. Furthermore, this relationship was not observed in our study, where mean photosynthetic rates did not differ significantly between treatments.

Duan et al. (1996) found higher stomatal conductance in mycorrhizal plants than in controls and ascribed this to increased water absorption capacity of roots, which even in dry soils results simultaneously in a decrease in leaf resistance. Similar results were obtained in our experiments, although the soil was always moist.

We found that mycorrhizal plants had higher $\mathrm{Cu}$ levels in their root systems than controls. Roots of mycorrhizal banana plants contained $150 \%$ more $\mathrm{Cu}$ than shoots, which suggests that although AMF increase the amount of $\mathrm{Cu}$ accumulated in the roots, they may also protect shoots from an excess of heavy metals (Sylvia and Williams 1992).

Mn was translocated in large amounts to shoots. This effect is contrary to that observed in soybeans by Bethlenfalvay and Franson (1989) and in most studies with AMF (Nogueira 1996), but similar to that recorded by Medeiros et al. (1995) in experiments with sorghum. The results suggest that AMF effects on levels of $\mathrm{MN}$ in the aerial parts of plants may differ according to host species and fungal isolate.

That mycorrhizal plants showed reduced levels of $\mathrm{K}$, $\mathrm{Ca}$ and $\mathrm{Mg}$ in shoots and $\mathrm{Mn}$ in roots, compared with non-mycorrhizal plants, may be explained by the dilution effect of the increased dry mass of mycorrhizal plants (Jarrel and Beverly 1981). This effect is common in studies comparing levels of nutrients in plants with and without mycorrhizas.

Brazanti et al. (1992) observed no differences in mineral contents of mycorrhizal and non-mycorrhizal plants, even when supplemented with P. Although, we found no statistical differences in concentrations of $P$, $\mathrm{Ca}$, and $\mathrm{Zn}$ in roots and $\mathrm{P}$ in shoots between inoculated and non-inoculated plants, the total contents of these elements were significantly higher in mycorrhizal than in non-mycorrhizal plants. In general, elements with low mobility in the soil, such as $\mathrm{P}, \mathrm{Cu}$ and $\mathrm{Zn}$, are absorbed in higher amounts by mycorrhizal than by nonmycorrhizal plants (Stribley 1987; Colozzi-Filho and Balota 1994). In our work, the concentrations of $\mathrm{Cu}$ and $\mathrm{Zn}$ in roots and shoots, respectively, point to such an effect.

Menge et al. (1978) and Jaizme-Vega and Azcón (1991) considered inoculation with AMF a good strategy for successful plant transplantation because of improved water and nutrient absorption. In our experiments, inoculation with AMF increased growth of mi- cropropagated banana plantlets during the acclimatization period, and this may benefit rates of photosynthesis and also nutrient transport by mass flow. Isolates of both native and introduced AMF improved the growth and the nutritional status of banana plantlets and this may have importance for banana plantations.

Acknowledgements The authors thank Dr. David Sylvia for discussions about the manuscript and the anonymous reviewers for their valuable suggestions. This work was supported financially by Embrapa Semi-Árido and FACEPE. L.C. M. and A.M.Y. M. acknowledge the fellowships provided by CNPq.

\section{References}

Allen MF, Smith WK, Moore TS, Christensen M (1981) Comparative water relations and photosynthesis of mycorrhizal and non-mycorrhizal Bouteloa gracilis H.B.K. ex Steud. New Phytol 88:683-693

Azcón-Aguilar C, Cantos M, Troncoso A, Barea JM (1997) Benefical effect of arbuscular mycorrhizas on acclimatization of micropropagated cassava plantlets. Sci Hortic 72:63-71

Berta G, Trotta AF, Hooker J, Munro R, Atkinson D, Giovanetti M, Marini S, Loreti F, Tisserant B, Gianinazzi-Pearson V, Gianinazzi S (1995) The effects of arbuscular mycorrhizal infection on plant growth, root system morphology and soluble protein content in Prunus cerasifera L. Tree Physiol 15:281-293

Bethlenfalvay GJ, Franson RL (1989) Manganese toxicity alleviated by mycorrhizae in soybean. J Plant Nutr 12:953-970

Brazanti B, Gianinazzi-Pearson V, Gianinazzi S (1992) Influence of phosphate fertilization on the growth and nutrient status of micropropagated apple infected with endomycorrhizal fungi during the weaning stage. Agronomie 12:841-845

Colozzi-Filho A, Balota GL (1994) Micorrizas. In: Hungria M, Araújo RS (eds) Manual de métodos empregados no estudo da microbiologia agrícola. Embrapa-SPI/CNPAF/CNPSo, Brasília, pp 383-418

Declerck S, Devos B, Delvaux B, Plenchette C (1994) Growth response of micropropagated banana plants to VAM inoculation. Fruits 49:103-109

Declerck S, Plenchette C, Strullu DG (1995) Mycorrhizal dependency of banana (Musa acuminata, AAA group) cultivar. Plant Soil 176:183-187

Dixon RK, Marx DH (1987) Mycorrhizae. In: Bonga JM, Durzan DJ (eds) Cell and tissue culture in forestry. (Forestry Science, vol 2) Nijhoff, Dordrecht

Douds DD Jr, Galvez L, Bécard G, Kapulnik Y (1998) Regulation of arbuscular mycorrhizal development by plant host and fungus species in alfafa. New Phytol 138:27-35

Duan X, Neiman DS, Reiber JM, Green CD, Saxton AM, Augé RM (1996) Mycorrhizal influence on hydraulic and hormonal factors implicated in the control of stomatal conductance during drought. J Exp Bot 47:1541-1550

Fortuna P, Citernesi S, Morini S, Giovannetti M, Loreti F (1992) Infectivity and effectiveness of different species of arbuscular mycorrhizal fungi in micropropagated plants of $\mathrm{Mr} \mathrm{S} \mathrm{2/5} \mathrm{plum}$ rootstock. Agronomie 12:825-829

Freeden AL, Terry N (1987) Influence of vesicular-arbuscular mycorrhizal infection and soil phosphorus level on growth and carbon metabolism of soybean. Can J Bot 66:2311-2316

Giovannetti M, Mosse B (1980) An evaluation of techniques for measuring vesicular arbuscular mycorrhizal infection in roots. New Phytol 84:489-500

Guillemin JP, Gianinazzi S, Trouvelot A (1992) Screening of arbuscular endomycorrhizal fungi for establishment of micropropagated pineapple plants. Agronomie 12:831-836 
Giullemin JP, Gianinazzi S, Gianinazzi-Pearson V, Marchal J (1995) Influence des endomycorhizes à arbuscules sur la croissance et la nutrition minérale de vitroplants d'ananas dans un sol à forte salinité. Fruits 50:333-341

Granger RL, Plenchette C, Fortin JA (1983) Effect of a vesicular arbuscular (VA) endomycorrhizal fungus (Glomus epigaeum) on the growth and leaf mineral content of two apple clones propagated in vitro. Can J Plant Sci 63:551-555

Grattapaglia D, Machado MA (1990) Micropropagação. In: Torres AC, Caldas LS (eds) Técnicas e aplicações da cultura de tecidos de plantas. ABCTP/Embrapa-CNPH, Brasília, pp 99-170

Harris D, Pacovsky RS, Paul EA (1985) Carbon economy of soybean, Rhizobium, Glomus associations. New Phytol $101: 427-440$

Hewitt EJ (1966) Sand and water culture methods used in the study of plant nutrition. Commonwealth Agricultural Bureau, Farnham Royal, UK, pp 187-237

Jaizme-Vega MC, Azcón R (1991) Effect of vesicular-arbuscular mycorrhizal fungi on pineapple [Ananas comosus (L.) Merr] in the Canary Isles. Fruits 46:47-50

Jaizme-Vega MC, Galan-Savco V, Cabrera Cabrera J (1991) Preliminary results of VAM effects on banana under field conditions. Fruits 46:19-22

Jaizme-Vega MC, Tenoury P, Pinochet J, Jaumot M (1997) Interactions between the root-knot nematode Meloidogyne incognita and Glomus mosseae in banana. Plant Soil 196:27-35

Jarrel WN, Beverly RB (1981) The dilution effect in plant nutrition studies. Adv Agron 34:197-224

Jenkins WR (1964) A rapid centrifugal-flotation technique for separating nematodes from soil. Plant Dis Rep 48:692

Lin CH, Chang DCN (1987) Effect of three Glomus endomycorrhizal fungi on the growth of micropropagated banana plantlets. Trans Mycol Soc Rep China 2:37-45

Mathur N, Vyas A (1995) In vitro production of Glomus deserticola in association with Ziziphus nummularia. Plant Cell Rep $14: 735-737$
Medeiros CAB, Clark RB, Ellis JR (1995) Effects of excess manganese on mineral uptake in mycorrhizal sorghum. J Plant Nutr 18:201-217

Menge JÁ, Davis RM, Johnson EL, Zentmyer GA (1978) Mycorrhizal fungi increase growth and reduce transplant injury in avocado. Calif Agric 32:6-7

Monteiro SEM, Matos RMB, Paula MA, Guerra JGM (1991) Micorrizas vesículo-arbusculares em bananeiras: aclimatação e transplante de mudas micropropagadas. In: Reunião Brasileira sobre micorriza, 4, Mendes, R.J.Resumo. Mendes: Embrapa-CNPBS/UFRRJ, p 163

Murashige T, Skoog F (1962) A revised medium for rapid growth and bioassay with tobacco tissue cultures. Physiol Plant $15: 473-497$

Nogueira AV (1996) As micorrizas e o excesso de metais. In: Siqueira JO (ed) Avanços em fundamentos e aplicação de micorrizas. Universidade Federal de Lavras (DCS, DCF), Lavras, Brasil, pp 135-174

Phillips JM, Haymann DS (1970) Improved procedures for clearing and staining parasitic and vesicular arbuscular mycorrhizal fungi for rapid assessment of infection. Trans Br Mycol Soc $55: 158-161$

Siqueira JO (1994) Micorrizas. In: Araújo RS, Hungria M (eds) Microrganismos de importância agrícola. Embrapa-CNPAF, Embrapa-CNPSo, Embrapa-SPI, Brasília, pp 151-194

Stribley DP (1987) Mineral nutrition. In: Safir GR (ed) Ecophysiology of VA mycorrhizal plants. CRC, Boca Raton, Fla, pp 59-70

Sylvia DM, Williams SE (1992) Vesicular-arbuscular mycorrhizae and environmental stress. In: Bethlenfalvay GJ, Linderman RG (eds) Mycorrhizae in sustainable agriculture. Special Publication 54. ASA, Madison, Wisc, pp 101-124 